\title{
Indigenous Knowledge, Agricultural Practices and Adaptation in the Marginal Uplands: The Case of Brgy. Linao, Inopacan, Leyte
}

\author{
Jedess Miladel N. Salomon ${ }^{1}$, Annabella B. Tulin² and Janice \\ Marie S. Monderondo ${ }^{2}$
}

${ }^{1}$ National Abaca Research Center, Visayas State University, ${ }^{2}$ Philippine Root Crops Research and Training Center, Visayas State University

\begin{abstract}
This study documented how upland farm households make use of the available, albeit meager, resources in their environment. Through focus groups discussions, household interviews and observation, it attempts to understand how they make use of their intimate knowledge of their surroundings to make a livelihood. More than half of the 30 households included in the study were tenants. Their agricultural practices were based on traditional beliefs and years of observation and experience on when to plant, how to ensure a bountiful harvest, soil management and pest control. Crops which are drought-resistant and require no agro-chemicals were preferred. Moreover, they classified soil based on color and texture. This was their guide in planting certain crops in each type of soil. It was common for them to have two or more sources of income because farm produce was not enough to meet their basic needs. These include wage laboring and selling of goods.

This case study illustrates the importance of indigenous or local knowledge to agriculture by providing farm households with adaptive strategies. It is therefore important that this knowledge system be taken into account in the development and implementation of programs which aim to improve the agricultural and economic productivity of farm households in marginal uplands.
\end{abstract}

Keywords: agriculture, soil classification, coping and adaptation

Correspondence : J.M.N. Salomon Address: National Abaca Research Center, Visayas State University Email:jedessmilade113@yahoo.com

DOI: $10.32945 / a t r 36 s 3.2014$ 


\section{INTRODUCTION}

People living in the marginal uplands are among the "poorest of the poor" as they live off of lands having very low crop productivity due to poor soil quality, limited water availability and unfavorable socio-economic conditions (Asio, 2013; Hart and Vorster, 2006). Most resource-poor farmers in marginalized areas practice low-external-input agriculture (LEIA) with minimal or no support from research and extension services (Hart and Vorster, 2006). Despite this, they have managed to develop a knowledge system of local practices that has been an effective and efficient coping strategy (ibid.). However, little is known about how they survive amidst such resource scarcity and poverty. Moreover, since agriculture in the marginal uplands involves the use of limited natural and socioeconomic resources, the uncertainty of its sustainability is of foremost concern. In order to achieve sustainable development, economic growth, in which agriculture is an integral part, must be partnered with social equity and the preservation of natural resources. Through a case study of a village located in one of the marginal uplands in Leyte, this study aimed to identify, describe and document upland farmers' knowledge and agricultural practices to understand how they have adapted to poor agricultural conditions. From these, inferences can be drawn on how to best use these indigenous practices for sustainable livelihoods and resources.

Brgy. Linao is a village in the marginal uplands of the municipality of Inopacan in the province of Leyte, Philippines. The people in the barangay have lived and toiled in the uplands for years. There, water is scarce and the soil is dry. The summers, bringing high temperatures and little rain, are especially unforgiving to crops. However, armed with knowledge accumulated through years of experience and passed down from generation to generation of upland farmers, they continue to survive in these circumstances.

It is this particular knowledge set, popularly termed as indigenous or local knowledge, which has enabled them to continue farming despite the uplands' unfavorable conditions. Indigenous knowledge can be broadly defined as the knowledge that an indigenous (local community accumulates over generations of living in a particular environment. This definition encompasses all forms of knowledge - technologies, know-how skills, practices and beliefs - that enable the community to achieve stable livelihoods in their environment. The significance of indigenous 
knowledge to adaptation is such that it is based on observations and experimentation by previous generations which are then transferred to the next generation. There is then that connection between people and their changing environments (Cohen et al., 1998 in Ajani; Mgbenka and Okeke, 2013). Moreover, indigenous knowledge is 'increasingly exhibiting a resemblance with scientific methods as many ideas in indigenous knowledge that were once regarded as primitive and misguided, are now seen as appropriate and sophisticated' (Ajani, Mgbenka and Okeke, 2013). It cannot be denied that 'local peoples are knowledgeable about their soils, lands, plants and environment and well qualified to define their own problems' (Barrera-Bassols and Zinck, 2003).It is within this context that this study has the following specific objectives:

1. Determine how upland farmers name, describe and classify their soils and how they manage their cropping systems in relation to the soil;

2. Describe their knowledge and beliefs on farming and how these influence their farming decisions and practices; and

3. Determine information sources and other sources of income apart from farming.

Within the framework of sustainable development, where poverty alleviation and environmental sustainability are keys, understanding and integration of indigenous knowledge is vital. For many years, development efforts have been moving from top-down modernization approaches to bottom-up participation. It is no longer about transferring and adopting technology to fix problems, rather understanding local knowledge and realities in order to respond to the needs of local communities (Sillitoe and Marzano, 2009; Sillitoe, 1998). Thus, understanding upland farmers' knowledge exhibited through their agricultural practices would guide the implementation of development projects that would not disrupt the adaptive strategies that work best for them in their environment and "provide a foundation for locally-appropriate sustainable development" (UNESCO, 2014). 


\section{METHODOLOGY}

\section{The study site}

Linao is one of the 20 barangays of Inopacan, a fourth-class municipality in the province of Leyte (Figure 1). Its name is derived from the Cebuano word linaw, which refers to a body of freshwater akin to a lagoon. According to old residents, there was a distinctively big linaw in the barangay before. Its infrastructures: barangay hall, health center, school and basketball court, are located in its plains. Most of the roads leading to various points in the barangay, particularly those leading to the uplands, were rough roads. The main mode of transportation is the motorcycle, locally called habalhabal, although four-wheeled vehicles can still access the uplands.

Data on its population slightly vary with the National Statistics Office's (NSO) 2010 census indicating 829 residents, while the Barangay Council recorded 920 . Approximately $15 \%$ of the population live and farm in the uplands. In the recent zoning, the barangay is divided into seven zones or puroks: 1, 2, 3, 4, 5, 6 and 7. Part of Purok 6 and the entire Purok 7 are located in the uplands. These zones were formerly collectively called Sitio Batuan, and are referred to as such even until the present. This was the focus of the case study. It was selected as the study site for the following reasons: 1) it fit the category of a marginal upland: the soil was noticeably dry and infertile, patches of land were cultivated but with minimal productivity, water sources were scarce and the people living off of the land were poor, and 2) the relative accessibility of the sitio compared to the other areas considered.

In the mid-1900s, Sitio Batuan had only about ten households who then migrated to other municipalities due to the insurgency in the 1980s. According to informants, it was only in the year 2000 that the sitio experienced an influx of migration. In the early years, the area was mainly covered with cogon (Imperata cylindrica). Only a few portions of the area were cultivated as it was difficult for the farmers to control the cogon. Even then, the soil was dry and infertile. During the time of fieldwork, a large part of the uplands was developed for agriculture. The houses in the sitio were built near the road, on top of the hills and along the few waterways. The number of houses and vegetation decreased toward the peak of the upland where a great portion was barren or covered with cogon. 


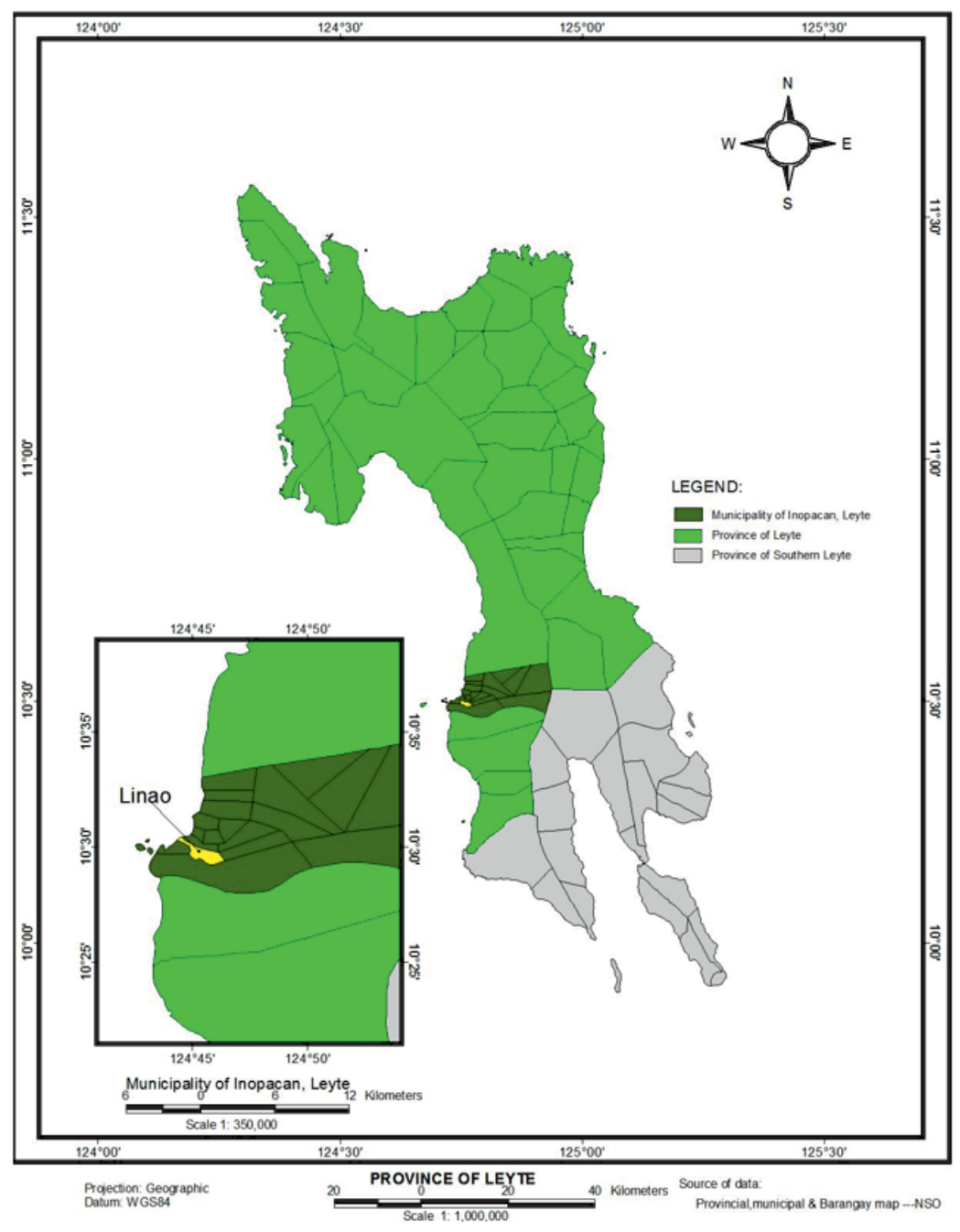

Figure 1. Map of the study site: Brgy. Linao, Inopacan, Leyte

Source: Ecological Farm and Resource Management Institute ([ECOFARM], (2013)

\section{Research methods}

The study team conducted initial visits to establish rapport with the residents, gathered data from barangay documents and conducted focus group discussions (FGDs) on the barangay's history, traditions, general use of resources and current problems associated with these. Detailed information on the barangay's resources and agricultural practices were 
Knowledge, practices and adaptation in the marginal uplands

gathered from March to August 2013 through semi-structured interviews with 30 informants, majority of whom were tenants, from Sitio Batuan. Table 1 shows their demographic characteristics. Of the farmers interviewed, 21 were tenants and only nine were landowners. Informants' farm sizes, based on their estimates, range from 0.01 ha to 3.04ha with a median area of $0.625 \mathrm{ha}$. The semi-structured interviews also elicited informants' knowledge, attitude and perception on their access and use of resources in their environment.

Table 1. Characteristics of informants

\begin{tabular}{lccc}
\hline \multicolumn{1}{c}{ Category of informants } & Male & Female & Total \\
\hline Tenants & 11 & 10 & 21 \\
Landowners & 4 & 5 & 9 \\
Total number of informants & & & 30 \\
\hline
\end{tabular}

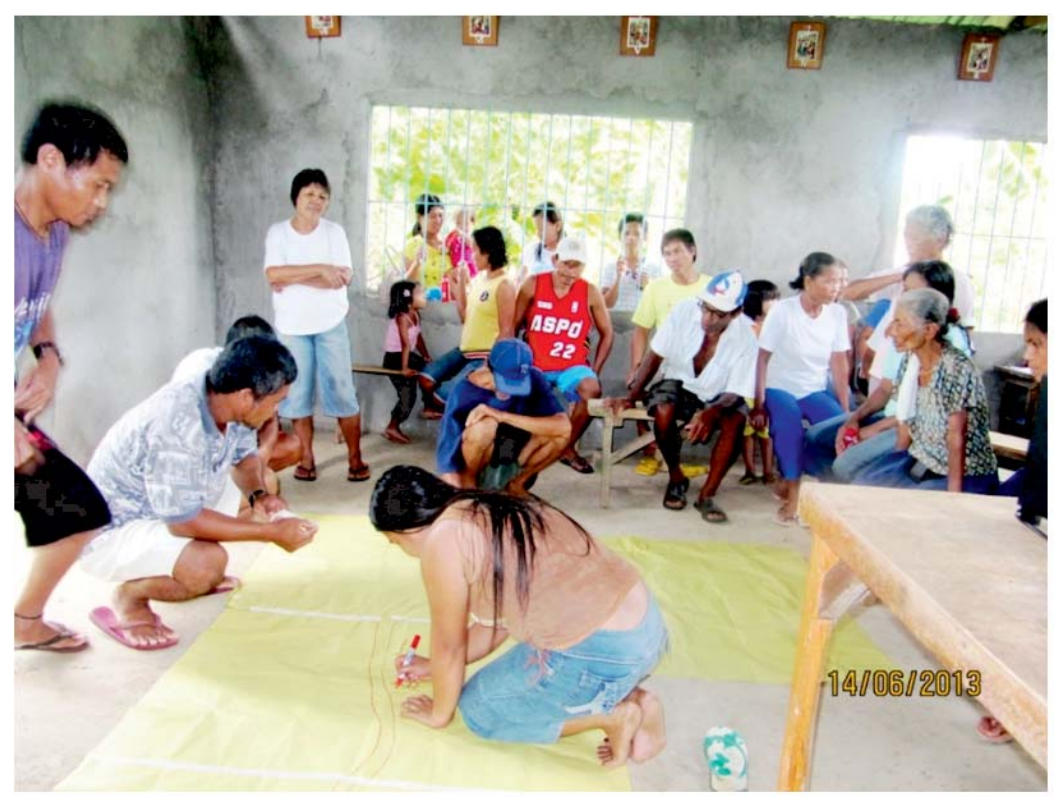

Figure 2. Participatory mapping conducted with some residents of Sitio, Batuan Inopacan, Leyte.

Data on the barangay's history and its present situation were taken from interviews with key informants: selected key officials of the 
barangay; the first elected barangay captain who was 90 years old at the time of the interview, selected residents at the peak of Sitio Batuan, and some children from Sitio Batuan who acted as guides during a transect.

In addition to these, participatory resource mapping (Figure 2) was done to indicate which resources were used and were significant to informants and where these were located. A researcher also lived in one informant's house to observe the community's routine activities for one week.

\section{RESULTS AND DISCUSSION}

\section{Agricultural practices}

According to Yule (n.d.), agriculture has produced more traditions, customs and superstitions than any other occupation of man. These are the basis for decision-making in agricultural production, natural resource management and other activities within a particular community or society (Rao and Ramana, 2007) and are generally recognized as key factors in increasing agricultural productivity (Olatokun and Ayanbode, 2008 in Motsumi, Magole and Kgathi, 2012).

\section{Traditional beliefs on farming}

In Sitio Batuan, agricultural practices were the result of both superstition and what Mettrick (1993 in Hart and Vorster, 2006) termed as 'indigenous technical knowledge', which the local people have on their environment and the technical aspect of their farming. This knowledge continues to expand through observation and experimentation. The agricultural practices of farmers in Sitio Batuan varies according to the kind of crop planted.

Farming superstitions involved attributing events to supernatural as opposed to natural causes. These were carried out in the form of rituals, repetitive practices which involved either magic or witchcraft (Lavenda and Schultz, 2003), and taboos (from a Polynesian term meaning prohibition), the breaking of which led to undesirable consequences or "bad luck" (Gmelch, 2000).

There were specific times of the year which were observed and believed to be the best time to plant for a bountiful harvest. Generally, crops were planted during the full moon for full harvest. Farmers also 
observed the tides as low tide indicated an abundant harvest because during this, the abundance of the underwater could be seen. Sweetpotato was only planted in August to produce big tubers. Informants attested that sweetpotato planted in May and June does not produce any tubers, only leaves. Coconut was planted at noon so that it will bear nuts early, while it is still young and short. There was also an informant who stated that his crops were productive during years ending in odd numbers, while the opposite happened during years ending in even numbers.

There were rituals to ensure plenteous and good quality harvest. As prelude to a bountiful rice harvest, a few kilograms of rice would be harvested three days before the actual harvest, a small amount of which was placed at the altars of the farmers' houses and the rest was cooked and shared with neighbors who helped in planting. To ensure that fruit trees would produce sweet fruits, sugar was placed on the first emerging fruits. Sweetpotato, according to one informant, produced many tubers when he expressed his appreciation for it even before harvesting (e.g. "Daghana ug unod ahong kamote oy." "My sweetpotato produces a lot of tubers."). One informant recalled a time when he was a young boy and his mother would bring him to their plot on a clear night as good luck to their sweetpotato so that these will produce tubers "as many as the stars". One informant places a fruit of the nipa with the coconut he plants so that the characteristic of the nipa, which is early fruit-bearing, will be transferred to the coconut. This was preferable for farmers who do not want to climb tall coconut trees.

There were also superstitions regarding pest and disease control. Upon seeding of corn, a piece of coal is sown together with the grain. The coal served as limot or a way to mislead the crop pest. The coal's dark color was believed to shield the seed from being identified by pests. Also, the farmer should not turn to look back at his field after planting so that pests would not recognize the area where the seeds were sown and turn towards the seeds. Rats and the maya bird (Passer montanus) were kept away from crops through hunghong, or whispering against these pests.

There was also a popular story of a farm in the barangay that was protected against thieves by a spell/curse. There was reportedly an instance when someone picked up a coconut which fell to the ground in the farm and he died within a few days with a bloated belly. Since that day, no one in the barangay dared to venture into that particular farm.

However, informants argued that, although they observe some of these rituals and taboos passed on to them by their elders, some of these were far from reality. They instead relied on the things they observed as basis for 
decision-making in farming. Farmers do not necessarily believe in the effects of rituals and taboos grounded on supernatural causality, but they observed these as additional safeguards and/or simply as part of tradition.

\section{Soil classification and management}

The farmer's knowledge of the soil is a result of years of observation and experience. Hence, understanding this knowledge is a huge part of understanding their realities (Saito et al., 2006). Soil classification is a part of such knowledge and is significant in developing optimal land management practices for each specific soil and landscape types (Krasilnikov and Tabor, n.d.). This is particularly essential to an agricultural community such as Sitio Batuan, where the soil is one of the most important parts of the environment, since its residents' livelihood is dependent on soil fertility and crop productivity (Barrera-Bassols and Zinck, 2003, Krasilnikov and Tabor, n.d.). As is commonly found in surveys in Africa, America and Asia (Barrera-Bassols and Zinck, 2003, Saito et al., 2006), soil is classified according to color and texture. Table 2 shows the different soil types in the sitio as classified by the informants.

Informants had classified soil into two, according to soil color: puwa (or red), which is infertile, and itom (or dark), which is fertile. This classification is similar to the indigenous classification of farmers in degraded marginal uplands of Pinabacdao, Samar. Likewise, this was their guide in planting certain crops in each type of soil. String beans, corn, rice, and fruit trees (banana, jackfruit, marang, rambutan and passion fruit) were planted in dark, fertile soil. Informants related that some of the trees in the sitio grew from the seeds brought as droppings of birds which fed on a certain weed called hatutuknaw (Melastous malabathricum). Almost any type of crop can be planted in this type of soil, except cassava because, according to informants, it would turn bitter when planted in dark soil. On the other hand, only sweetpotato or camote and cassava were planted in the red, infertile soil since these crops could tolerate low levels of water and nutrients. These observations and practice of informants were validated through the soil chemical analysis done in the study site which showed that red soil was low in phosphorus $(\mathrm{P}=3)$ and organic matter content $(\% \mathrm{OM}=4.69)$ with only a medium amount of nitrogen (Total $\mathrm{N}=0.22)$, and was highly acidic $(\mathrm{pH}=5.3)$. Dark soil color, on the other hand, indicated a high amount of organic matter which supplies and retains nutrients in the soil (USDA, 1996). Sitio Batuan generally had red soil, while dark 
soil was found in areas near the lowlands and under trees.

Hambon and tabunok were other terms given to fertile soil, while umaw was another term for degraded soil. Buga and pansil/pansilado were terms used to describe rocky soil; the term buga specifically pertains to hardened clay that becomes as hard as stone, and therefore cannot support plant growth. This type of soil was found near water sources.

Sitio Batuan was once called Pansil for its rocky soil. This is in contrast with the lower part of Brgy. Linao which was once called Tabunok because it had mostly fertile soil. According to informants, the poor soil quality in the uplands was aggravated by continuous, excessive plowing. Plowing was practiced as a way of controlling weeds. However, one informant asserted that the soil at the peak area of Sitio Batuan can still be productive if properly managed.

Table 2. Types of soil according to descriptors and associated crops

\begin{tabular}{lll}
\hline \multicolumn{1}{c}{ Type of soil } & \multicolumn{1}{c}{ Description } & \multicolumn{1}{c}{ Associated crops } \\
\hline Color & Red soil, infertile & $\begin{array}{l}\text { Sweetpotato and cassava } \\
\text { Puwa, umaw }\end{array}$ \\
$\begin{array}{l}\text { Itom, hambon, tabunok } \\
\text { fruit trees }\end{array}$ \\
$\begin{array}{l}\text { Texture } \\
\text { Buga }\end{array}$ & Nork, rice and \\
Pansil/pansilado & Hardened clay & None \\
\hline
\end{tabular}

Some informants also had other soil fertility and vulnerability indicators to erosion. One informant indicated that when a particular area was barren, where even weeds did not grow, the soil in that area was infertile (Figure 3). On the other hand, the dark green leaves of plants indicated fertile soil. Another informant related that she tried to grow malunggay (Moringa oleifera) in an area near their house several times, however these did not survive. These observations reflect that informants know how to diagnose nutrient deficiency in the soil, although, they could not specifically identify which particular nutrients were lacking.

Moreover, an informant described the soil in Sitio Batuan as "maayo ug pugong" or hardly washed out or eroded. He said he cannot remember an instance of heavy soil erosion, although, there were some claims of minimal erosion in some parts of the village during the flashflood in Guinsaugon, Southern Leyte in 2006. He surmised that there must be a big rock underneath the soil supporting it against erosion. However, some 
informants believe that overplowing the field can lead to soil erosion and degradation. There are also those who believe that kaingin or burning of vegetation can cause soil degradation. Plowing was a common practice of farmers as it loosens the soil and uproots weeds in preparation for planting. Plowing in the steep, dry slopes of the uplands is one of the causes of soil erosion (Brown, 2012). Kaingin, on the other hand, was hardly done as the vegetation was not dense in the upland and was only done to control cogon. There were also times when fires were unintentionally started by a cigarette or a torch which were irresponsibly handled.

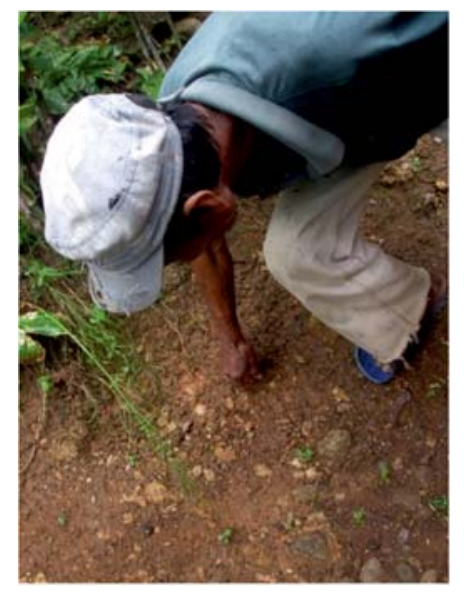

Figure 3. An informant illustrating one of his ways of telling that the soil is infertile, "Sama niin nga dyutay ray sagbot o tanom nga nabuhi (Like this where only few weeds or plants survive)."

To counter soil infertility, informants used cover crops like vietnam/asyang (Mikania cordata) and hagonoy (Chromolaena odorata (L.) as soil conditioners. These plants grew extensively in the sitio and, although generally considered as weeds, they are rich in nitrogen. To a lesser extent, cacao (Theobroma cacao) contributed to soil fertility in areas where it was planted. Farmers did not burn leaves that fell from the cacao trees, but left them on the ground instead, to decompose. They also practiced crop rotation to replenish nutrients, especially nitrogen, and shifting cultivation to allow the soil to regenerate. When they perceived that a crop did not grow well, they replaced it with another crop as they believed, through years of observation and experimentation, that planting the same crop for successive cropping seasons uses up the nutrients in the soil. When a particular crop fails to grow well in a cropping season, 
it was replaced with another in the next. Such perception is correct as monoculture not only decreases available nutrients for plant growth, but also increases crop-specific pests and diseases over time (Thierfelder and Wall, n.d.).

\section{Crops planted}

Agricultural production in Sitio Batuan was both for subsistence and commercial purposes. Informants who have lived in Batuan since the 1960s recalled that sugarcane, rice and corn were their primary crops. There was a sugarcane farm in the barangay then, which was equipped with an intosan (sugar mill) and they produced binagol (sugar compacted in a coconut shell). A carabao turned the mill. Rice and corn, together with some rootcrops were both grown in the lowlands and uplands. When the National Irrigation Administration (NIA) established an irrigation system in the 1970s, the area planted to sugarcane was converted to rice and corn fields. Sugar processing consequently stopped. Root crops, particularly cassava and sweetpotato, were grown, to a smaller extent, in both the uplands and lowlands. Also, people in the barangay planted vegetables in their backyards for food. A crop which was not popular then was coconut because of its low selling price. During the time of fieldwork, coconut trees were cultivated but many of these had yellow leaves, exhibiting nutrient deficiency.

The most common crops cultivated by informants at the time of fieldwork were sweetpotato, cassava and banana. According to them, these were the crops which could tolerate the infertile and dry soil of the uplands. These crops did not need constant watering which made it less laborious for farmers, especially during the dry spells of summer, since the few water sources were a long distance from their plots. Moreover, these crops did not need many inputs. Most resource-poor farmers cannot afford agrochemical fertilizers and pesticides. Some informants even feared that the soil might be worse-off if these chemicals were applied and then discontinued. Hence, these were applied exclusively to rice by the farmers who grew the crop. Rice was no longer commonly cultivated in the sitio as it required many agro-chemicals and an abundant supply of water. Out of the 30 informants, only three grew rice. In the marginal uplands, crops which were generally drought-tolerant, required very little inputs and labor, and yet produced sufficient yield were preferred over those which required many inputs. These crops, and the knowledge on how to grow them, becomes important to food security (Hart and Vorster, 2006). 
In some areas, informants planted trees to control growth of weeds, especially cogon. The presence of Ipil-ipil (Leucaena leucocephala) provided shade that hindered the growth of cogon which thrives well in an open area exposed to sunlight. Informants also stepped on the weeds, instead of uprooting them, and left them on the ground to decompose (informants call this practice hapi). This was a way of controlling weeds and fertilizing the soil. Others burn the cogon to control its spread to their plots.

Since agro-chemical pesticides were applied exclusively to rice, two informants ingeniously made use of other available materials. One jackfruit grower experimented with two plant extracts: panyawan (Tinospora rumphili) and tubli (Milletia piscatoria Merr.), by combining and fermenting these to produce an organic pesticide. He combined and fermented the two plant extracts. One informant sprayed soap dissolved in water on his crops to control pests.

\section{Sources of farming information and assistance}

Generally, informants' knowledge, beliefs and practices on farming were either passed down from the older generation or gleaned from years of observation and experience. Most of the informants stated that no one from the Department of Agriculture (DA) or the local government unit visited their area or assisted them in any way. They asserted that the project researchers were the first to visit their area.

Only three informants reported of having undergone training or received assistance from the government. One underwent a school-onthe-air training on sweetpotato production. Another received fertilizer (urea) for his coconuts and another said that people from VSU and the Department of Environmental and Natural Resources (DENR) gave Gmelina planting materials. He recalled it was part of an International Centre for Research in Agroforestry (ICRAF) project. He remembered it well because, according to him, the project was responsible for the trees growing in a few areas in the uplands. Before the project, these areas were only covered with cogon.

\section{Other sources of income}

Farming in the marginal uplands is a risky livelihood because of the difficult conditions, meager natural resources and the poor socio- 
economic circumstances of farm households. Hence, they usually employ other livelihood strategies to cope and adapt (Hart and Vorster, 2006). Some households in Sitio Batuan engage in enterprises, profitable or not.

One female informant sold coconut vinegar from tuba (coconut wine) for P30.00 per container (approx. 2 liters). Tuba, on the other hand, was sold for P60.00 per gallon. One gallon of tuba per day was produced from two coconut trees. According to her, selling tuba was not very profitable because her husband and his friends usually consume the tuba themselves. She added that the coloring ingredient for tuba called tungog (this makes the tuba red; without it, the tuba looks just like water) was getting expensive. Red tuba was preferred by consumers that was why they needed to mix in the tungog. Moreover, the number of tuba gatherers has decreased because they preferred to engage in other more profitable activities and enterprises. This reflects how households cannot carry out an increasing number of tasks without giving up other livelihood activities (Hart and Vorster, 2006).

On the other hand, one profitable venture that a farm household engaged in was furniture-making. A couple who were both farmers made bamboo furniture sets during their spare time to add to their income from the farm. With only P400.00 as capital, they earned as much as P2,000.00 per set. They did not have to spend much on the raw materials since bamboo was readily available from their surroundings. Because this was profitable, they made bamboo furniture regularly and were providing two sets a month to a furniture retailer in Baybay City.

\section{CONCLUSIONS AND IMPLICATIONS}

The study's findings are supported by existing literature and experiences which show that local farmers possess indigenous knowledge about their environment which they use to adapt to the harsh conditions and limited resources of the marginal uplands. These indigenous knowledge systems provided them with coping mechanisms to thrive in degraded uplands. Their understanding of the soil and its properties, their diagnosis of nutrient deficiencies and their ingenuity in using available, limited resources helped them manage their agricultural practices to lessen soil degradation, prevent erosion, control crop pests and ensure a harvest (although not a productive one in every cropping season) (Matanmi, 2001). 
This does not mean, however, that indigenous knowledge is equal to, or better than scientific knowledge (Hart and Vorster, 2006). Research on indigenous knowledge for application in development projects must be respectful and, at the same time, sensible especially when dealing with superstitions. These must be respected as part of culture but should not be romanticized. Even the farmers in the study who practiced some of the rituals relied more on observation and years of experience in making farm decisions rather than on superstition. A study by Stifel, Fafchamps and Minten (2009) even dealt on the impacts of work taboos on agriculture and poverty, and found that farmers in Madagascar could have been more productive if they did not observe such taboos.

This study also shows that agriculture in the marginal uplands is not limited to subsistence. Farmers in the marginal uplands, have the capacity to produce beyond what they consume. Moreover, they have the capacity to engage in other livelihood strategies that add to their household income, thus contributing to the economy and food security of a locality. Such contribution should be subject to further research.

However, farm households' livelihood strategies are still limited to the available and accessible natural and financial resources. The adoption of technologies and recommended farming strategies is dependent on farmers' resources and realities (Hart and Vorster, 2006). This must be taken into account in the implementation of development projects.

\section{RECOMMENDATIONS}

With these conclusions, this study has the following recommendations:

1. Research, development and extension activities which aim to improve the living conditions of marginal farm households should be guided by studies which look at the indigenous knowledge, practices and realities of local communities. An understanding of the different realities of farm households in different localities will make development efforts more responsive to their needs.

2. The focus of research and development in the marginal uplands must be on sustainable livelihoods and not only on increasing yields to combat poverty (and food insecurity). Along with this should be the restoration of the degraded environment and management of natural resources. 
3. In connection to sustainable livelihoods, a livelihoods analysis must be done to assess households' resources and livelihoods strategies in order to determine strategies or a combination of strategies to establish sustainable livelihoods taking into account the context of their environment.

4. Although transportation to farms in the marginal uplands is relatively difficult and time-consuming compared to farms in the lowlands, the Department of Agriculture and the local government of Inopacan must pay attention to these farmers and their farms. They are part of the agricultural production of the country and the ones needing the most assistance. It is important that the access roads from farm to market must be constructed to facilitate the trading of farm produce.

\section{REFERENCES}

AJANI, E.N., R.N. MGBENKA and M.N. OKEKE. 2013. Use of indigenous knowledge as a strategy for climate change adaptation among farmers in sub-Saharan Africa: implications for policy. Asian Journal of Agricultural Extension, Economics and Sociology 2(1):23-40.

ASIO, V.B. 2013. Marginal uplands: current research initiatives at VSU. Retrieved September 20,2013 from http://soilenvironment.blogspot.com/2013/03/marginal-uplands-currentresearch.html

BARRERA-BASSOLS, N. and J.A. ZINCK. 2003. Ethnopedology: a worldwide view on the soil knowledge of local people. Geoderma 111:171-195.

BROWN, L.R. 2012. Full planet, empty plates: the new geopolitics of food scarcity.Retrieved October 14, 2013 from_http://www.earthpolicy.org/books/fpep/fpepch5

GMELCH, G. 2000. Baseball magic. In: Conformity and conflict: reading in cultural anthropology $11^{\text {th }}$ ed (J. Spradley \& D. McCurdy eds.). Allyn \& Bacon, U.S.A.

HART, T. and I. VORSTER. 2006. Indigenous knowledge on the South African landscape: potentials for agricultural development. Human Sciences Research Council (HSRC) Press, Cape Town, South Africa. 
KRASILINIKOV, P. and J. TABOR. n.d. Ethnopedology and soil folk taxonomies. Soils, plant growth and crop production 3. Retrieved September 21, 2013 from http://www.eolss.net/sample-chapters/c10/E1-05A-3500.pdf

LAVENDA, R.H. and E.A. SCHULTZ. 2003. Core concepts in cultural anthropology, $2^{\text {nd }}$ edition. McGraw-Hill Higher Education, U.S.A.

MATANMI, B.M. 2001. Indigenous knowledge in agricultural production in Northern Nigeria: the use of astronomy. Retrieved September 19, 2013 from http://www.unilorin.edu.ng/publications/matanmi/ Indigenous_knowledge_in_agricultural_production_in_northern_nige ria.pdf

MOTSUMI, S., L. MAGOLE and D. KGATHI. 2012. Indigenous knowledge and land use policy: Implications for livelihoodsof flood recession farming communities in the Okavango Delta, Botswana. Physics and Chemistry of the Earth 50-52:185-195.

NATIONAL STATISTICS OFFICE (NSO). 2010. 2010 census of population and housing. Retrieved September 26, 2013 from http://www.census.gov.ph/sites/default/files/attachments/hsd/pre ssrelease/Eastern\%20Visayas.pdf

RAO, V.L.N. and G.V. RAMANA. 2007. Indigenous Knowledge, Conservation and Management of Natural Resources among Primitive Tribal Groupsof Andhra Pradesh.Anthropology today: trends, scope and applications 3:129-134. Retrieved September 17, 2013 from http://www.krepublishers.com/06-Special\%20Volume-Journal/TAnth-00-Special\%20Volumes/T-Anth-SI-03-Anth-Today-Web/AnthSI-03-11-Rao-V-L-N/Anth-SI-03-11-Rao-V-L-N-Tt.pdf

SAITO, K., B. LINQUIST, B. KEOBUALAPHA, T. SHIRAIWA \& T. HORIE. 2006. Farmers' knowledge of soils in relation to cropping practices: a case study of farmers in upland rice based slash-and-burn systems of northern Laos. Geoderma 136:64-74. 
Knowledge, practices and adaptation in the marginal uplands

SILLITOE, P. 1998. The development of indigenous knowledge: a new applied anthropology. Current Anthropology 39(2):223-252.

SILLITOE, P. \& M. MARZANO. 2009. Future of indigenous knowledge research in development. Futures 41:13-23.

STIFEL, D., M. FAFCHAMPS \& B. MINTEN. 2009. Taboos, agriculture and poverty. University of Oxford.

THIERFELDER, C. \& P.C. WALL. n.d. The importance of crop rotations. CIMMYT International Maize and Wheat Improvement Center. Retrieved October 10, 2013 from http://www.wiso.boku.ac.at /fileadmin/_/H73/H733/Mozambique/CIMMYT_ExtBulletins02.pdf

UNITED STATES DEPARTMENT OF AGRICULTURE (USDA). 1996. Soil quality indicators: organic matter.

YULE, E.S. n.d. Some superstitions and customs of Filipino farmers. Retrieved October 10, 2013 from http://archive.org/stream/jstor29738348/29738348_djvu.txt 